\title{
FORMS OF SATURATION. DISCRETE AND CONTINUOUS EVENTS IN ARCHITECTURAL DESIGN
}

\author{
A B S T R A C T
}

This essay addresses the opportunities and limits of architectural design at the juncture of technology and disciplinary specific developments in architecture. The theoretical model that it develops encapsulates the essences of what it means to work with respectively digital and analogue modeling systems. It poses a release from the continuous crisis of architectural education in coping with the onslaught of the digital. Moreover, it addresses the uncritical obsession that architectural academia has with this technology without relapsing into the various forms of reactionary practices that are currently emerging in the profession as well as the schools.

The discussion focuses on systems and regimes of representation within architectural design and production and problematizes the role of digital and computational design procedures with respect to analogue systems of representation, architecture's infinite construction of our physical environment and the inherent limitations of digital systems given their 'rational' character.

The essay attempts to address the influence and status of the digital by focusing on an inclusive notion of space. This is both architectural space but also the productive design space in which architects work. In unfolding the argument, three artworks have been discussed and the initial premise for the argument is based on art theory.

KEY WORDS

Städelschule Architecture Class, 


\section{INTRODUCTION: WHATEVER HAPPENED TO ARCHITECTURE?}

The power of the much celebrated and now ubiquitous 'digital' in architecture is its computational capacity, the capacity to numerically parse and literally construct and execute propositions with unthinkable complexity. This complexity may reflect as well as influence both intrinsic and extrinsic relations in the proposition - the latter perfectly exemplified by questions of manufacture, construction and the context for a project. Intrinsic relations may include materiality, geometry and the interconnection between parts within a whole. The entirety of a proposition and its relations comprise a space, first and foremost a space of production but eventually also architectural space inasmuch as an architectural proposition anticipates and describes forms of building.

Computerized processes and an extended understanding of the computational, which typically addresses material behavior and any set of influencing relations briefly outlined above, have not only become hugely influential on architectural thinking and practice, they largely set out the horizon of the discipline's future development. The problem, however, is that the rationalizing power of the digital and computational at best distorts the space of production in architecture and at worst reduces it to the singularity of the computable. Let it suffice to say rhetorically that lived reality always appears abundant in what is beyond the purely rational: the unaccountable, un-rostered and incomputable.

The problem has in part been explained when the way that the digital renders architecture rational is considered. The discourse on the digital and computational assumes that architecture is well planned if it reflects the economy and thus the efficacy of, for instance, material behavior, natural phenomena or - so popular nowadays - anticipated ecological performance. It is the powers of digital technology that makes this possible. Words like 'flow' and 'network' are abundant in this discourse, and architecture is celebrated if it assimilates, embeds or literally results from a maximum amount of responsiveness to one or another form of an extrinsic economy. In other words - so the arguments, or rather, contentions go - architecture becomes plausible and consistent with the ideas well-conceived and formulated simply because they are computed. Typically, this has come to coincide with formal, geometric or compositional complexity in architectural and urban forms. The digital delivers this complexity with relative ease and expediency so that the theoretical reasons for seeking alternatives to the Cartesian measure for space and Euclidean forms, as developed in the early 1990s, are all but forgotten. Current architectural thought skirts questions about architecture per se and is 
largely submerged in an extra-disciplinary euphoria of technology or else an escape into a political landscape wherein architecture belongs but that does not necessarily belong to architecture in disciplinary terms.

Thus, within an emerging neo-conservative society, fostered by the uneasiness and rigidity that follow economic crisis, architecture is bereft of ideas that address its disciplinary status other than attempts that explore its extended axes into technology, nature and politics. For instance, network theory is 'interesting' not because it belongs to architecture or is architectural but because the growth of trees can partly be explained by the dynamics of networks and their branching. Likewise, 'flow' conditions and phenomena are addressed not because they are central to questions of architectural space or the structural negotiation of forces in architectural form but because they represent a certain morphology and economy of exchange in our lived and, ideally, natural environment.

While embracing the digital as a set of tools and the computational as the ultimate procedural method for architectural design in technical terms, it is necessary to ask whatever happened to architecture as a cultural artefact? Whatever happened to the otherness of baroque sensibility so beautifully yet fragilely rendered in the facade of Borromini's San Carlo alle Quattro Fontane in Rome? Or the pre-modern stylistic intricacies of the Saxon State Opera in Dresden, also known as the Semperoper and designed by Gottfried Semper in 1841 ? And, way outside architecture, whatever happened to all those things that silently moved in the margins that Jacques Derrida so meticulously and poetically traced and described?

\section{THE GRAMMAR OF THE INEFFABLE}

The contemporary importance of the digital and computational notwithstanding, architecture is a cultural artefact, as artificial as they come, and deeply integrated with human life far beyond what is calculable. It is artificial as opposed to natural since it is human-made, a construct of parts just like James Joyce's written language and no more nor no less political than the life of Joyce's main character, Leopold Bloom, in the novel, Ulysses (1922). The book tells the story of an ordinary day in Leopold's life, June 16, 1904. In the 18th and the last episode of the novel, Joyce renders Molly Bloom's streamof-consciousness at the end of the day without any form of punctuation. Fifty pages are densely filled with the ebb and flow of Molly's remembrances as she lies in bed next to her husband, Leopold. These are pages of technical 
bravura and literary rapture, capturing Molly's reminiscences and her life with Leopold. Towards the very end of the episode, Joyce's syntax reaches a climax, the saturated pulse of ecstasy, that would be the literary embodiment of marital affairs.

Throughout the episode, the flow of thoughts and feelings, past and recent events, are tangible yet not divided. One moment in Molly's life flows into another while the language comes in ebb and flow, in crescendo and calmando. As a reader, one is engrossed in a space where the details of Molly's narrative bridges her physical experiences and being with the vibrancy of her emotions. Her remembrance is a literary synthesis of virtual and physical being. The structure of it all is one while discreet moments remain singularities - letters, words and phrases - that at once point backward as well as forward in association and grammatical allegiance.

In this manner the structure of Joyce's language bridges past and present, the remembrance of the flesh and the vagrancy of thought. It synthesizes the continuity of lived experience and the discontinuity of a detached moment. The syntactical synthesis renders the language replete with linguistic and grammatical events - a sheer fauna of verbs, nouns, pronouns, adverbs, adjectives, prepositions, conjunctions and interjections, all blissfully joined in an ecstasy of language. The totality of Molly's remembrance is saturated with these discrete moments, each charged with an emotion and an experience and yet framed within a continuity of an incalculable, lived life.

Joyce's eminently constructed language, beautifully brought to a climax on these last pages of Ulysses, forecasts a shadow over the omnifarious potential of the digital and computational. Molly's life at the end of the book cannot be computed, nor does Joyce's language surrender to the workings of a grammatological apparatus. Yet, resistance to integer systems of order and production is not the question. 'What else is out there?', however, is. (Fig. 01)

\section{THE DISCRETE AND THE CONTINUOUS}

Nearly half-a-century after the publication of Ulysses, the American philosopher, Nelson Goodman, published his seminal book in analytical aesthetics, Languages of Art: An Approach to a Theory of Symbols (1968). In it Goodman addresses symbol systems of representation in art; to him all artworks are made up of symbols that must be interpreted relative to a set of references within a system of rules. The relation between a referential context 
and a concomitant symbol system works in both directions, one influences the other. Goodman's intricate theory of symbol systems delivers a systematic way to approach and understand art, yet - paradoxically - it also delivers a space of innovation. This is a materially generated interstice accommodating the ambiguous or the 'what else' that is out there, anticipating the 'frivolous' space of innovation that Derrida later comes to unearth between the regimented, historically layers of philosophical epistemology. ${ }^{1}$

A crude and reductive account of Goodman's theory sees him distinguish between symbolic schemes of description, which relies on resemblance to that which it refers to, and representation, which does not rely on resemblance. Representation is a far denser realm than description. The latter is articulate, unambiguous and is rendered by a discontinuity of discrete elements. Representation, on the other hand, is ambiguous and replete; it is both syntactically and semantically dense. Goodman writes: 'A scheme is syntactically dense if it provides for infinitely many characters so ordered that between each two there is a third. In such a scheme, $[\ldots]$ no mark can be determined to belong to one rather than to many other characters. ${ }^{2}$ In other words, in a representational scheme entities may have an equivocal status, which renders the entire system ambiguous. Entities may point this way or that; thus they may associate themselves to more than one reference at any one time. If discrete elements can be identified, their status and symbolic allegiance within the scheme remains ambiguous due to their multivalent association to other regions within the artwork.

Goodman argues that aesthetic representation in art constitutes a syntactic repleteness given its syntactic and semantic density. The art object presents this form of saturation not because of its autonomous status but because it must always be understood within the vast contexts of authorship and readership, and because its materiality reverberates with a fleshiness that is closer to Molly Bloom's life than to the calculable commands of computable experience.

In the last instance, Goodman's theory of art sets forth a space of ambiguity within the symbol systems that he constructs, and this ambiguity arises from the incalculable material and artistic forms that Goodman examines and uses to construct his theory.

\section{The Ambiguity and Fineness of the Analogue}

The art historian, Whitney Davis, has argued that painting as an art is 'a classic analogue mode of representation', and he has used part of Goodman's 


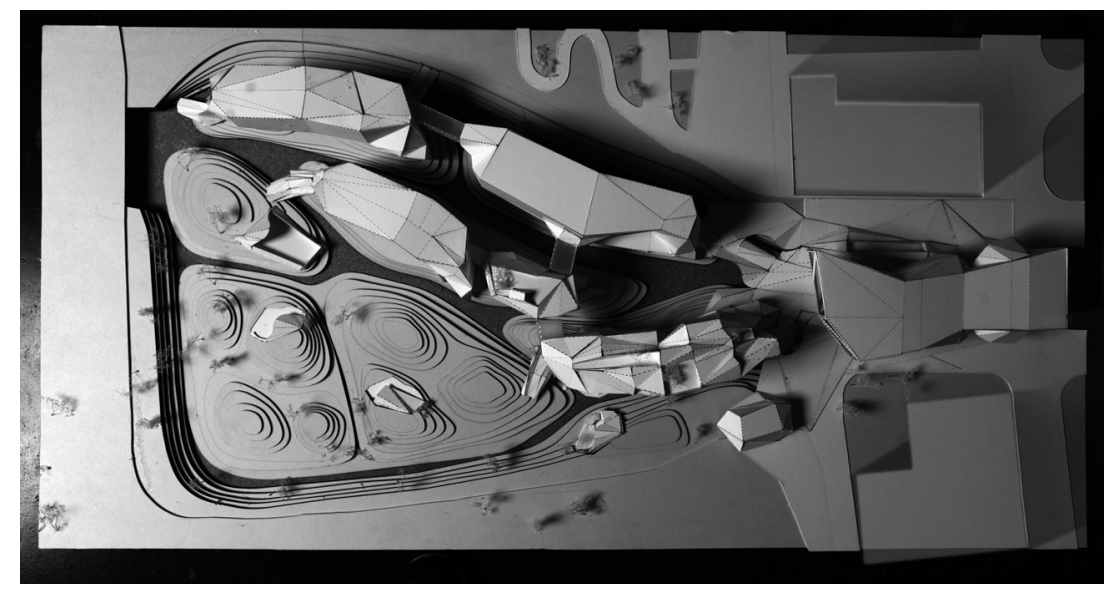

Figure 01.
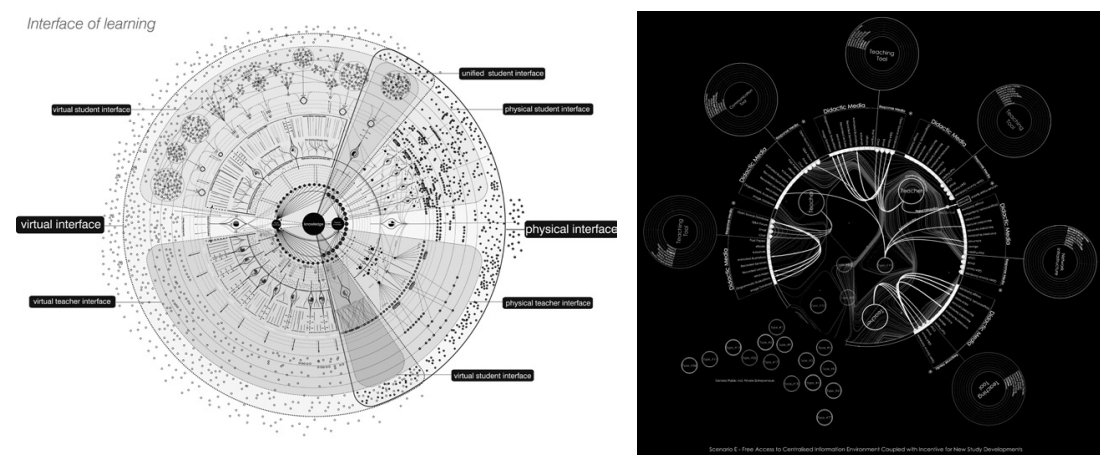

Figure 02.

Figure 03. 
theory to ' $[\ldots]$ gauge the depth and direction of digital technologies of image production (phenomena, appearance, representation) [...]' relative painting's analogue status. Davis argues that Goodman may have written his book as a 'foundational explication (and to some extent a critique) of contemporary vocabularies of information, computation, and representation. ${ }^{3}$

The emergence of digital technology around the time when Goodman wrote and published his book gave rise to the assumption that electronic automation and digital computation represented precision whereas the analogue was about approximation. Davis writes: 'Languages of Art addressed this prejudice: it proposed rigorous terms within which the "sensitivity and flexibility" of analogue symbol systems (including symbol systems identified with vision, natural language, and the arts) could be compared systematically - and often favorably - with the "definiteness and repeatability" attainable with digital computing machines. As Goodman urged, the key issue - it is phenomenal, echnical, logical, social, cultural, and ethical - is to settle "the maximum required fineness of discrimination" to be relayed in a representation or computed by a machine. ${ }^{34}$ To the digitally initiated, Goodman's notion of "fineness of discrimination" should recall the unit, module or component in parametric (associative) and algorithmic (scripted) modeling procedures. These are the essential, discrete elements that allow repeatability, calculability and rational computational processes - whether in the form of geometry or the syntax of a computer language.

However, in Goodman's argument, "fineness of discrimination" is also the ability to discern difference within a complex and difficult whole, difference that resists being parsed into calculable units and that arises from within ambiguous terms that call for "sensitivity and flexibility". For instance, fine distinctions can be made within Joyce's language as Molly's day comes to an end, yet the language cannot be resolved and unambiguously divided in accordance with a normative syntax. Linguistic measures must remain coarse since there is an ill fit between Molly's stream of consciousness and the normative logic of a grammatical structure based on subjects and verbs, punctuation and so on. Hence, Goodman's "fineness of discrimination" may or may not deliver the discrete units required for computation; it will depend on the 'complex and difficult whole'. This, in turn, leads us to the question of settling "the maximum required" resolution within the whole "to be relayed in a representation or computed by a machine.' (Fig. 02)

"To settle [this “...] fineness of discrimination"” draws on our ability to read the artwork or the proposition within its context. This ability to settle - that 
is, unequivocally define - a unit on the basis of which further action can be based, is not merely a technological question but also an intrinsic opportunity that arises from within the work in question based on its material substrate. So, for instance, the equivocality of Joyce's language arises from the multivalent potential for linguistic association within the language itself given the context of Molly's narrative. A given word or utterance may point backward or forward in the sentence, jump across immediate association to the preceding word or utterance and vaguely tie itself in with a more distant linguistic event. It is an equivocality that implies the continued coexistence of two or more possibilities, which, as we shall see, is a condition that falls outside of the digital realm.

\section{Material Surplus and Resistance}

In Goodman's argument, the materiality of an artwork - regardless of discipline - resists the convenient rationalization of calculability or computation. $\mathrm{He}$ writes: 'If representing is a matter of classifying objects rather than imitating them, of characterizing rather than of copying, it is not a matter of passive reporting. The object does not sit as a docile model with its attributes neatly separated and thrust out for us to admire and portray. It is one of countless objects, and may be grouped with any selection of them; and for every grouping there is an attribute of the object. To admit all classification on equal footing amounts to making no classification at all. Classification involves preferment; and application of a label (picture, verbal, etc.) as often effects as it records a classification. The 'natural' kinds are simply those we are in the habit of picking out for and by labeling. Moreover, the object itself is not ready-made but results from a way of taking the world. The making of a picture commonly participates in making what is to be pictured. The object and its aspects depend upon organization; and labels of all sorts are tools of organization.'5

Goodman used the paintings of Hokusai, the late $18^{\text {th }}$ and early $19^{\text {th }}$ century Japanese master, to argue his point. Comparing the diagrammatic nature of an electrocardiogram and Hokusai's drawing of Mount Fuji, Goodman writes: 'The difference is syntactic: the constitutive aspects of the diagrammatic as compared with the pictorial character are expressly and narrowly restricted [...] Any thickening or thinning of the line, its color, its contrast with the background, its size, even the qualities of the paper - none of these is ruled out, none can be ignored. Though the pictorial and diagrammatic schemes are alike in not being articulate, some features that are constitutive in the pictorial scheme are dismissed as contingent in the diagrammatic scheme; the symbols in the pictorial scheme are relatively replete. ${ }^{6}$ Goodman sees the materiality of the painting, given by its constituent material parts and the methods and technology 
that produced it, define a space that is saturated with symbolic potential and that resists a rational partitioning of its material and representational presence. The resistance means that the painting ultimately cannot be reduced to and coded in digital binary series consisting of zeros and ones. To Goodman, the problem with this encoding of information is its fixed duality; it is either this or that, either 'zero' or 'one'. The work of art always represents more, always generates a surplus and an in-between the given discrete states ('zero' or 'one') that is ambiguous in what relations are generated. The artwork always renders a relational status beyond a singular one-to-one transaction between a unit and what it represents.

Davis quotes John von Neumann, the Hungarian-born American mathematician and polymath, to explain what is at stake: "The decisive property of a switching organ is that it is almost always found in one or the other of its two extreme discrete states, and spends only very little time transiently in the intermediate states that form the connecting continuum." Davis expounds: 'Strictly speaking, "a [symbol] scheme is syntactically dense if it provides for infinitely many characters so ordered that between each two there is a third."” The transient, intermediate or the third state calls forth the analogue. It will be the fundamental technical-logical feature of analogue representation.

'In Hokusai's picture of the flank of Mount Fuji,' Davis continues, 'we sense that even if we were to magnify the image many times over we could continue to discover salient modulations of line. Rather than arriving, say, at identical and interchangeable pixels picking out identical and interchangeable units of Mount Fuji, we cannot discover any final, finite granulation. Even if we do discover dissimilar and nonexchangeable motifs (e.g., a tree-brushstroke here and a rock-brushstroke there), in principle the picture continues to afford apparently intermediate involutions and incarnations (a tree on a rock; a snowdrift between rock and tree, and so on). This possibility of infinitization and interminability establishes irreducible horizons for the very possibility of significance in the image. ${ }^{8}$ (Fig. 03)

Saturation per se, however - here given by the replete symbolic field, does not in and of itself render analogue systems capable and the digital incapable of handling the totality of the artwork. Rather, it is the analogue as a system of production - that is, as material-technological mechanisms of production, that render the qualities of saturation and ambiguity. In turn, these qualities that can never be dissociated from the processes of reading, loosely speaking what Goodman continuously refers to as the context, which means that they cannot be dissociated from the experiencing or inhabiting subject. 
The ambiguous quality of Goodman's replete symbolic field implicitly anticipates theoretical and conceptual preoccupations that addressed complexity in architectural theory of the 1990s. This discourse engaged with the concept of the virtual, as opposed to the ideal, and described the realm of production - in particular with respect to geometric form - as relying on the vast potential of a virtual space filled with possible forms. The ideal was contrary to this, giving - as variations on historical theory and stylistic themes tell us, a one-to-one relationship between an ideal form and its realization. To engage with the virtual and, certainly, to immerse oneself in a replete symbolic field imply acts of constructing the world. They constitute a creative space insofar as reading, projecting and assigning possible meaning to the world are part of the construction process. According to Goodman, this act of constructing presumes pre-given symbol systems within which the world is understood by way of it being labeled and predicated. Thus, the vagrancies within such a system - including the changeability of the system itself, anticipate and echo the lessons had from the philosophy of deconstruction. However, a re-reading of Goodman offers architecture something that deconstructionist philosophy did not, namely a more precise and potentially instrumental approach to the principal architectural act of construction, which is the design process. One key word would be 'saturation'. The question would be where and how to locate it other than in Goodman's theory of symbols?

\section{SATURATED SPACE IN THREE WORKS OF ART}

One may wonder, what would the spatial equivalent of Goodman's pictorial space be? What would possibly exemplify the saturated space of "symbols" within our lived, spatial-temporal experience?

In the recent Ruhrtriennale 2013, International Festival of the Arts, directed by the German composer and theatre director, Heiner Goebbels, two installations by different artists went a long way to capture highly articulated conditions of a saturated space. They offered very different experiences. Where one was loud, the other was silent; where one depended on computers to deliver its intense and fluctuating experiential space, the other subtly played off the visitors' movements through the installation itself. The former was Ryoji Ikeda's test pattern [100 $\mathrm{m}$ version]; the latter was William Forsythe's Nowhere and Everywhere at the Same Time No. 2. These two art and choreographic works, respectively, establish different economies between, on one hand, the calculable and computational and, on the other hand, that which cannot be reduced to or captured by a computational strategy. However, beyond this 
spatial and representational economy, each work appears fully saturated - that is, replete with a layered, deep structure of navigational possibilities for the visitor. The irony is that it is the visitors, the inhabitants of the art that - so to say - complete the saturation of the respective spaces.

A third example of a saturated space, carefully choreographed yet noncomputable, is that of the contemporary dance and performance group, Mamaza, in their recently premiered piece, Eifo Efi. Eifo Efi does not invite its audience in as participants as the artworks referred to above did. Yet, more so than the other two, it renders the space of the artwork intensely saturated and in so doing echoes with the ambiguous plasticity of form and structure that is to be found in Joyce's Ulysses.

\section{Ryoji Ikeda: test pattern [100m version]}

Ryoji Ikeda, one of Japan's leading electronic composers and visual artists, installed a new version of his work, test pattern - appropriately called test pattern [100m version] - in the Kraftzentrale in Duisburg. ${ }^{9}$ The century old iron factory hosted Ikeda's installation with the immense floor of the main hall serving as a 13.3×100 meter long screen for his dynamic, dual band light projection while an intense, fluctuating pulse of sound accompanied the longitudinally oriented visual component. (Fig. 04)

Test pattern [100m version] was a fluctuating light- and soundscape, a beatdriven, inhabitable barcode; each longitudinal band presented extreme variations on dynamic, transverse barcode patterns in black and white. Of test pattern, Ikeda writes: 'Taking various forms - installations, live performance and recordings - test pattern acts as a system that converts any type of data (text, sounds, photos and movies) into barcode patterns and binary patterns of $0 \mathrm{~s}$ and $1 \mathrm{~s}$. The project aims to examine the relationship between critical points of device performance and the threshold of human perception, pushing both to their absolute limits. ${ }^{10}$ However, while Ikeda's work 'focuses on the essential characteristics of sound itself and that of visuals as light by means of both mathematical precision and mathematical aesthetics', ${ }^{11}$ one would miss the essence of the ' $100 \mathrm{~m}$ version' of test pattern in the Kraftzentrale if one would ignore that visitors inhabited the art work. The visual dimension of the work was not a screen in the conventional sense of the canvas in painting or paper in pictorial art. The installation offered an immersive environment, intersecting the technological system performance with 'the threshold of 
human perception'. Ten video projectors produced a flickering and pulsating ground for visitors to cross, stand or lie down on. Children would run and loudly yell to counter the rhythmic throbbing of the massive loudspeaker system; adults would sit, gather in small crowds and casually stroll down the immense onslaught of transverse light waves that passed in two equal-width bands from one end of the hall to the other. While the technological backdrop of the work was fully commensurable with Goodman's notion of the digital, its manifestation in visual and sonic shock waves - sometimes short, abrupt and dense and sometimes long, almost still and paradoxically quiet - did not render a space of discrete and discontinuous elements. Was it the rate of change in sound and light, perhaps the speed at which things travelled?

No, speeds of the barcode-like visual patterns and the sonic pulses, as they swept through the hall, were digitally produced. If broken down into their infinitesimal parts, each would be identifiable and stringently sequenced according to a computed logic. This already rendered the space of Ikeda's test pattern a hugely impressive experience, even seen at the distance from the balcony running alongside and above the Kraftzentrale's long-spanned floor. However, while one could remain the distant observer, one could also descend onto the floor, have one's body penetrated by the sonic pulses and washed by the projected ones. At this point one would be transformed from being a visitor to a digitally generated soundscape to an actor in it, a cursor of flesh and blood passing at impulse through a carefully calculated fauna of light and sound. And at once Ikeda's test pattern [100m version] was truly a test, incorporating the wildcard, the truly irrational, the vagrant human individual and smaller groups of them, presenting ambulating patterns across the floor, through the light, carrying the sonic pulses as much within as they were felt and heard outside, and soon all evaporated.

William Forsythe:

Nowhere and Everywhere at the Same Time No. 2

Meanwhile, at the Folkwang Museum in Essen, the American-born choreographer, William Forsythe presented his Nowhere and Everywhere at the Same Time No. 2. Like Ikeda's test pattern, Forsythe's piece was also not original but a new version of Nowhere and Everywhere previously presented, amongst other places, at the international exhibition The Plain of Heaven in New York in 2005 and at Tate Modern's Turbine Hall in 2009 as well as in the Venice Biennale in 2012. 

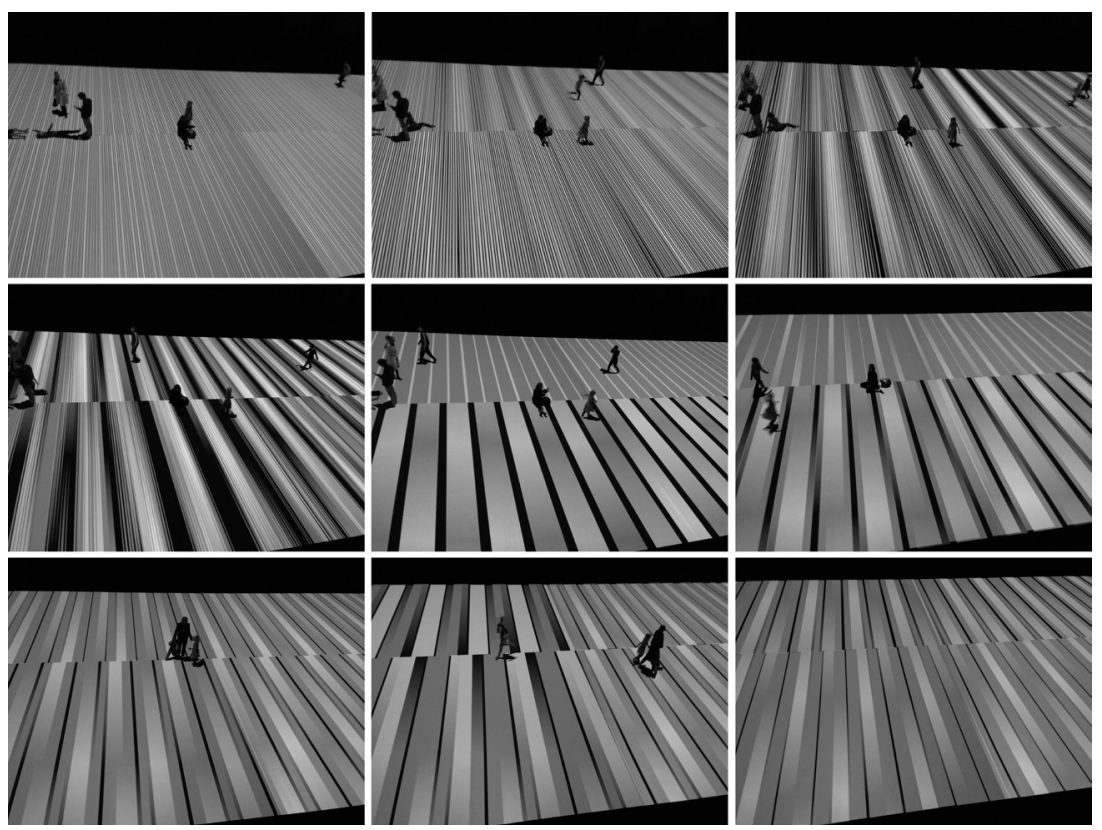

Figure 04.

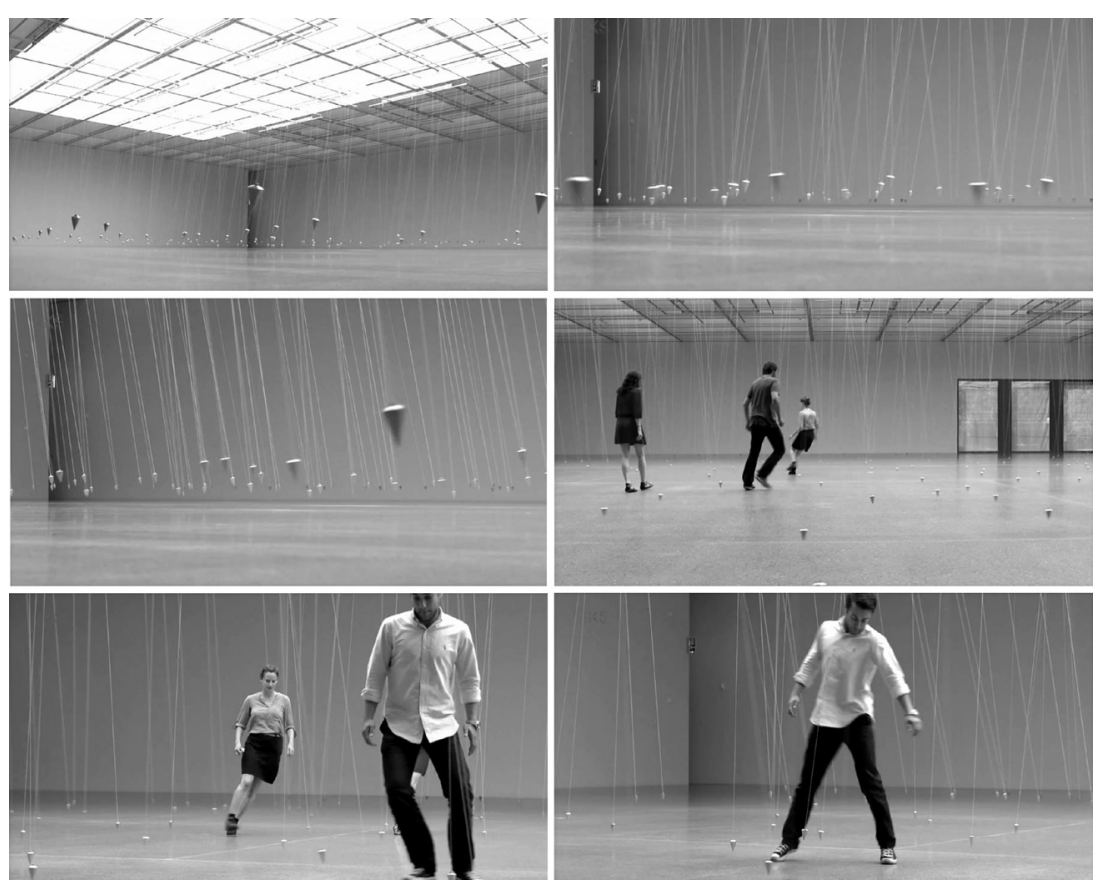

Figure 05 . 
'This new edition,' says the program of the Ruhrtriennale, 'preserves and privileges two central interests in Forsythe's oeuvre: counterpoint and the unconscious choreographic competence induced by choreographic situations. Suspended from automated grids, more than 400 pendulums are activated to initiate a sweeping 15 part counterpoint of tempi, spatial juxtapositions and gradients of centrifugal force which offers the spectator a constantly morphing labyrinth of significant complexity. The spectators are free to attempt a navigation of this statistically unpredictable environment, but are requested to avoid coming in contact with any of the swinging pendulums. This task, which automatically initiates and alerts the spectators innate predictive faculties, produces a lively choreography of manifold and intricate avoidance strategies.' ${ }^{12}$ (Fig. 05)

The logic of Nowhere and Everywhere No. 2, however, assumes that the spectators are not merely observers but that they in turn fulfill their roles as the antonym to a spectator, namely as active participants. While test pattern [100m version] is open to inhabitation, Nowhere and Everywhere invites if not demands that one participates, echoing the performance premise of its first staged version in New York almost ten years ago: "For "Plain of Heaven," [Forsythe] choreographs a new piece that forces the spatial imagination of a single performer to evolve and adapt. The dancer weaves among a field of hanging pendula, keeping them in motion but avoiding them, making manifest our circular and symbiotic relationship with the space around us. ${ }^{, 13}$

The initial field in Nowhere and Everywhere No. 2, consisting of the pendula and their subtly fluctuant movements, is already densely packed when the participants enter and nimbly or not so nimbly move between the thin strings undulating between the ceiling and the floor. Gravity, evenly distributed throughout the space of Folkwang's exhibition space, is normally the dominating force determining how we move. But no matter how thickly and evenly gravity is painted onto the large exhibition space, the pendula and the participants soon dissolve the predictable stability of bodily movement that gravity normally give rise to. A delicate yet oddly synchronized and erratic dance emerges. Or, with more than one participant, it is plural and polysynchronous: dances emerge.

Swinging pendul are interrelated and meshed with the participants' moving limbs, the air and heat they might stir, their bending and attempting to skirt the returning strings. Soon the total artwork is the most charming, odd and nervous spatial mechanism, saturated by playful and incalculable 'computations' with 
which the participants seek to avoid being caught in the undulating strings. Its ambiguity rests with the 'nowhere' and 'everywhere' of human positional computation as well as locations of the individual pendula. If there would have been no participants and an absolutely sealed and controllable, physical environment, the location of the individual pendula would have been singular or their rate of change zero or constant. The space might have been truly computable. Only, this is no laboratory; it is art.

\section{Mamaza: Eifo Efi}

Eifo $E f i$ had its world-premiere in Künstlerhaus Mousonturm in Frankfurt in mid-September 2013. Conceived and performed by Ioannis Mandafounis and Fabrice Mazliah of the dance collective Mamaza, Eifo Efi is a simple duet in a classical sense with the audience facing the small stage in parallel rows from the seating arena. Yet, while the piece also unfolds spatially on stage in classical sense, occupying its center and extending to its four axial peripheries in a phased manner, Eifo $E f$ engenders a stunningly complex layering and 'distinct alchemy of juxtaposition[s]' 14 of bodily movement, spoken language and performance intricacies. (Fig. 06)

Eifo Efi's begins with the dancers bursting onto stage with their bodily performances being accompanied by both dancers orally and simultaneously narrating a series of events. Their respective narrations approximate one another: sometimes they seem to converge; at other times they diverge. At times their stories are hinged around a single word that both use with a slight time delay between. The dual stories form two pulses, intimately interwoven yet never identical. The oral narration continues throughout the circa 50 minute piece with only the intensities and loudness of the voices fluctuating in the space. Concurrently, the dancers perform bodily figurations of the narrative content. At times, this is obvious and direct; at other times; there are subtle hints at a relation or none at all, merely a beautiful unfolding of bodily tension and relaxation in space. However, it could also be the other way round that the oral part of the performance attempts to frame the story of the dance.

In the latter case, Eifo $E f i$ hints at the idea that language has a gestural origin; our spoken form of communication once arose as a way to transpose gestural imperatives to uttered sound in order to increase efficacy and lessen the role of the visual. ${ }^{15}$ In either case, one of Eifo Efi's most distinct qualities is the physical use of the gestural in the form of dance. Of course, the irony will be that dance relies on vision and Eifo Efi enlists language as a second performative mode 
to lessen the reliance on its traditional and dominant form of communication. Yet, the second performative mode, language, relies in the first place on dance in its gestural form. That is, it is a nice irony of absolution.

Regardless of the economy of origin, Eifo $E f i$ sees its performers figuratively describe narratives with fingers, hands and arms; limbs, the relative positions of heads, individual as well as dual and loosely synchronized corporeal knots draw figures around the dancers as geometric cursors in space. Spatial locations, spatial-temporal nodes and narrative nexuses are indicated, embodied or unfolded at various speeds of corporeal and oral articulations.

The fleshy and viva voce performances present a higher order complexity through the approximately mirrored if not to say binary relation that Mandafounis and Mazliah deliver on stage. A performative realm of doubled identities, badly copied and mismatching reminiscences and tightly choreographed yet 'loosely coupled" ${ }^{16}$ dance ensues in palpitating time - a time that allows for the necessary slippages to accommodate Eifo Efi.

This dense, saturated space of Eifo Efi is remarkable for the fact that it is performed in real-time; it is at once the space of creation and of reading. It is intensely ambiguous since its narrative can never be resolved and the dance never comprehended in its entirety. The moment something congeals, it dissolves in the next - both moments, however, materially thickened in space as they are mirrored off the reflective surface with which the dance floor is covered. Obviously - due to the piece's narrative component, Molly Bloom's stream of consciousness comes to mind. Yet, while it shares a number of structural characteristics, it is also fundamentally different for the simple reason that Molly's reminiscences were constructed by language on a piece of paper. Eifo Efi unfolds in the space in front of the audience and is constructed by the vibrancies of the flesh and the voice. (Fig. 07)

The immediacy of performance - whether understood through the occupancy role that the visitor has in Ikeda's test pattern [100m version], as a participant in Forsythe's Nowhere and Everywhere No. 2 or in the form of Mandafounis and Mazliah's professional staging of Eifo Efi, tends to saturate the experiential space of the artwork. The immediacy of the pictorial sketch might be an analogue condition. When discussing Goodman's work, Davis quotes him and reports that "“none among the pictorial properties of a sketch can be dismissed as irrelevant." For the sake of simplicity, we can define density as conjoint conditions of (1) nondisjointness and (2) nonarticulation at the syntactic level, running in "parallel," as Goodman puts it, to conjoint conditions of (3) nondisjointness and 
(4) nonarticulation at the semantic level (i.e., repleteness). ${ }^{17}$ Saturation, in other words, may not only be understood formally and structurally on syntactical and semantic levels, its ambiguity may also be predicated by the human agency of performance through immediacy and presence.

\section{THE RETURN TO ARCHITECTURE: WHERE IS MOLLY?}

In architecture the agency of human performance is effectuated through occupancy, comparative to the roles of the visitors to Ikeda's test pattern $[100 \mathrm{~m}$ version], discussed above. Against the computed backdrop of its informationalmaterial elements, test pattern [100m version] presents the least definite case for analogue systems' 'nondisjoint' and 'nonarticulated' density. Its formal make-up is purely digital, much like advanced contemporary architecture through the digital planning and production processes of design, manufacture and construction appears. The agency of human performance - read: the human, experiential dimension of architectural programming - is a by-product that is often dismissed due to the workings of a real-estate market only too willing to turn spaces into the next investment, regardless of architectural intentions.

However, one can also not dismiss the often seductive aggregation of architectural forms and building components that the computational delivers. Carefully articulated gradients of openings in structural and non-structural surfaces match the beauty of minutely designed details and surface fluency. Yet, if one goes along with the basic argument above, there might be something that goes amiss in the perfectly computed constructability of an optimized and purely rational architectural design process. It may have to do with Goodman's case for analogue systems; it may also have to do with agency of human occupation. Lived realities are abundant in the unaccountable, un-rostered and incomputable; they emerge from individual, group and institutional cultures and present saturated conditions of opportunities driven and modulated the erratic fields of human caprice and behavior. (Fig. 08)

Yet, it is a comfort to know that there are no original ideas herein. Goodman published his ideas almost half-a-century ago, and almost concurrently related ideas addressing architecture in urban settings were being formulated.

\section{Toyo Ito and the Assimilation of Symbols}

Only a few years after the publication of Languages of Art - that is, from the beginning of the 1970s, Toyo Ito began formulating ideas in texts and projects 
that addressed new, architectural and urban conditions in Tokyo. According to Thomas Daniell, the editor of a recent book presenting select texts by Ito from the last 40 years, Ito has been a 'prolific' writer, one who writes 'in order to build and buil[ds] in order to write. ${ }^{18}$ In particular his early essays, commencing with The Logic of Uselessness in 1971, are of interest to the discussion herein.

Emerging at a time that saw the apogee of the 1960s intense general and urban development in Japan Ito's work was engaged with technology and its concomitant urban condition. He 'was [...] part of a generation that could no longer see technology as Japan's unproblematic salvation from wartime destruction, but as potentially destructive itself.' Yet, Ito never turned his back on technology but embraced it. When an increasingly polluted environment and sterilized culture made some contemporaries of Ito, for instance Tadao Ando, attempt to sequester architecture from the world, Ito fully accepted the given condition and rather extracted aspects from it to formulate ideas and projects. Later, in 1984 when completing his project, Silver Hut, Japan stood at the beginning of its most extreme period of postwar, economic development, and 'for Ito, the superficiality of the lifestyles being engendered by Japan's incredible new wealth was matched by the superficiality of its urban environment ...[Yet, rather than deny this condition] Ito wanted to distil the city's ever-intensifying nervous energy into a visual rhetoric for architectural design [...] Rather than the creation of iconic objects anchored within an amorphous, volatile context, his new ambition was to develop an iconography of the context itself [... $]^{19}$ (Fig. 09)

These ideas can be traced through design strategies to constructed, architectural form in a number of projects - not the least White- $U$ (1976, a house for his sister) and the Silver Hut (1984, Ito's own house). Yet, no project so directly tackles Ito's observations as the Tower of Winds in Yokohama (1986). Daniell notes that subsequently, around the early 1990s, 'Ito launched himself into the emerging urban conditions, encapsulating his objectives in the phrase 'design of atmosphere': the invention of a type of architecture that might register and visualize in real time all the invisible qualities of its surroundings. While this included variations in temperatures, breezes, odors, sounds - properties inseparable from their physical substrate - Ito also contended that the city's atmosphere was permeated with insubstantial flows of information, which we might subconsciously perceive and architecture should consciously represent. ${ }^{20}$ Ito's interest in this socio-cultural saturation of the urban context may on one hand seem obvious; nothing could be more evident than the informational saturation of space in the media age. Yet, as Daniell continuous 

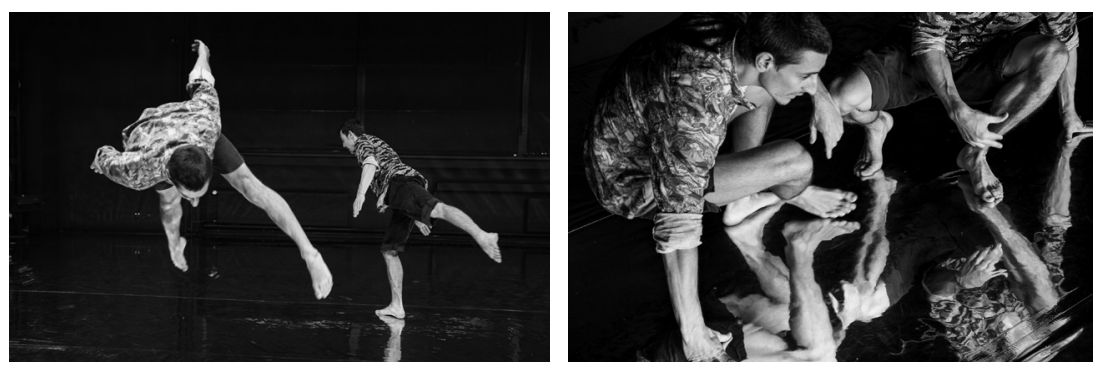

Figure 06.

Figure 07.

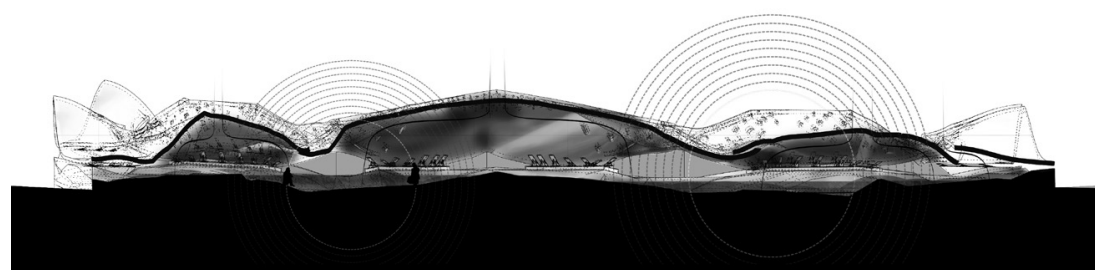

Figure 08.

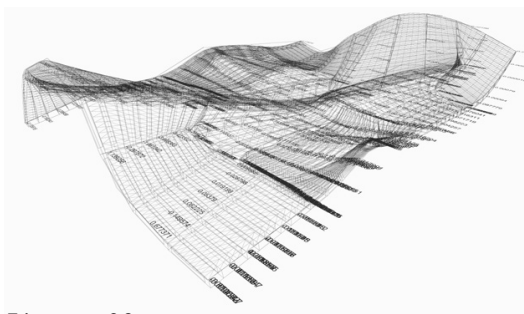

Figure 09.

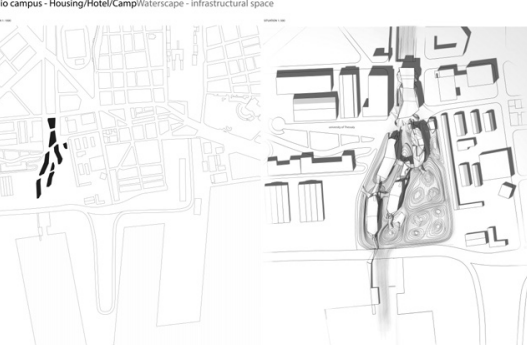

Figure 10.

Figure 11.
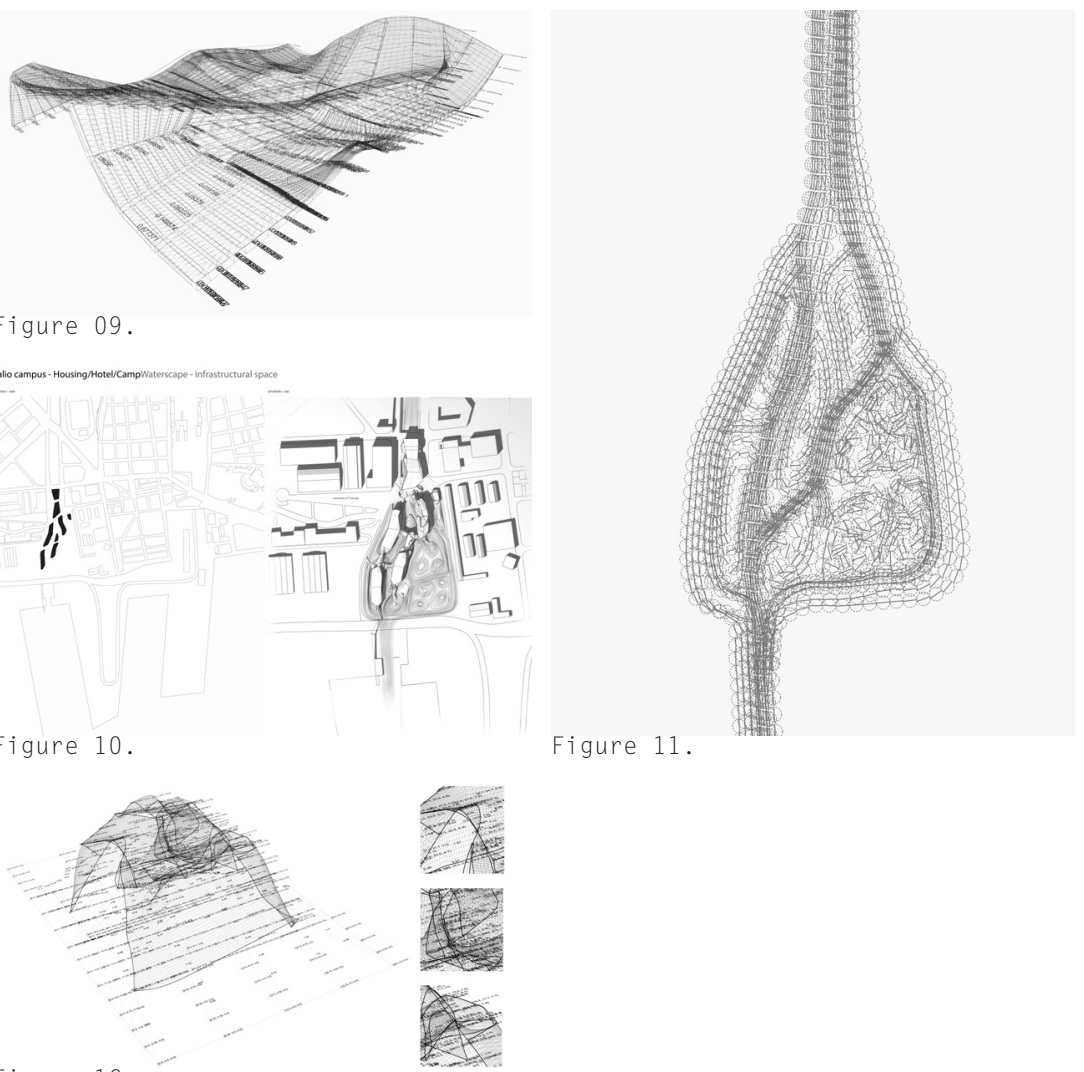

Figure 12. 
to explain: '... [Ito] intended the notion of information to be understood in the strictly materialist sense of electromagnetic fields: visible light, video transmissions, radio waves and so on. While our increasingly ubiquitous wireless communication networks might be thoughtlessly envisaged as cartoon lightning bolts leaping between mobile phones or personal computers, the reality is a kind of informational ether: an unthinkably complex interference pattern of overlapping spherical ripples propagating from innumerable sources at the speed of light. Ito's architecture of the 1980s, exemplified by the Tower of Winds in Yokohama, was an attempt to represent all of these flows poetically ... Built form is here conceived as a filter or sensor that somehow intercepts the flux of information, slowing and condensing it, making it momentarily perceptible, even palpable: architecture that flickers and buzzes like faulty neon, that is washed with intermittent static like a weak video signal, [...] that coats and thereby reveals the spectral outlines of the informational field, like water droplets modeling air turbulences or metal filings tracing a magnetic field. Ito again implies that he is not an author but an instrument, a medium - not imposing designs on the world, but manifesting its existing, unseen patterns. ${ }^{21}$

This manifestation of energetic flows was precisely what the Tower of Winds did, turning the impact of wind on the site into a dynamic, 360-degree image produced by a light installation just behind the transparent facade of the cylindrical building volume. However, the subtlety of Ito's stance as well as the delicacy of his theoretical musings, go far beyond a simple representational scheme - be it in the process transformational or not.

In his essay, Signs of Light (1977), Ito goes to great length resisting the normative role of symbols and their engendering meaning within systems of representation. Writing about the light within the urban fabric of Tokyo, Ito says: 'When making architecture in this city, even in the smallest houses, I will sever a piece of the fabric of light being produced by the city, and there enclose a field. For me, the only possible action is then to turn the severed, interwoven cross-sections into signs within this field. These signs are absolutely not converted into symbols. The aspects of light shifting together with the passage of time are codified into various tangible expressions. These are not incorporated within the system of meanings that exist in daily life, but are intended to become a fresh collection of codes of light. People absorb this collection of codes as they walk, and perhaps when the absorbed codes are rewoven inside each person, the field will begin to gain meaning through the medium of light. ${ }^{22}$ 
Ito's resistance to 'symbols' represents his resistance to conventional symbol systems - that is, the rigidity of fixed and pre-packaged information units and meaning. What he tells us, however, is that he appropriates 'a piece of the fabric of light being produced in the city' - in other words, a piece of the urban context in which he operates, and then proceeds to assimilate this in his architecture. This process of assimilation comprises turning the symbols into codes - that is, turning them from being fixed and reified informational units to individual sets of rules for converting a piece of information from one form to another. Moreover, this process of assimilation and transformation extends beyond the immediate architectural process of design and construction. 'People', that is the inhabitants of the space - recalling the role of the visitors to Ikeda's test pattern [100m version], become the executive agents for the process of transformation. They reweave the codes through reading and recontextualization, potentially enabling the emergence of new meaning (' $\ldots$ the field will begin to gain meaning through the medium of light'). (Fig. 10)

The entire process recalls the plasticity of replete, analogue symbol systems, as set out by Goodman. Difference, that is the potential for plastic transformation, is continuously engendered. Likewise, the continuous rather than the discontinuous status of the analogue enable a smooth and transformational process of assimilation and re-emergence of meaning which is based on the ambiguity lent to reading and re-contextualization, what Ito refers to as 'reweaving'. In his architecture, codes are generated from within and driven by the caprice of human agency; they are not imposed as totalizing and rationalizing sets of rules from the outside, rules that would impose strict oneto-one relations between the variables at hand.

\section{An Afterthought: The Infrastructure of It A11}

Architectural questions are always saturated problems; they are complex problems with multiple reference systems that bear on the initial, disciplinary and strictly formal question - be it an initial question of form, relations between parts, the status of the human participant or the context. Through the theoretical model that is developed herein, architecture becomes situated within a saturated technological and cultural space, reflecting contemporary political and social life as charged with opportunities for failure and success. In being always already saturated, the architectural questions anticipate the complex whole that the architecture end-result constitutes. 
For these reasons, architecture is never well addressed through digital and computational strategies and processes alone. These systems are reductive and present the danger of excluding marginal conditions and opportunities. Analogue systems, on the other hand, have in many contexts the advantage of offering moments of plastic transformation and, in consequence, unanticipated design opportunities. Symbol systems, as defined by Goodman, become open fields of production where the quality of ambiguity is - if not identical to, in the least exposed to and open for freedom and inclusivity. Hence, analogue systems are inclusive and continuous since they operate in and define saturated fields of information. Moreover, they are inherently material. (Fig. 11)

The material dimension of analogue systems is unique - notwithstanding the way computational systems are also used to analyze, simulate and model material behavior. Insofar as material systems 'compute', they nevertheless comprise analogicity since they operate on the basis of continuous material behavior properties yet often include inherent and irresolvable or paradoxical material condition. ${ }^{23}$ The material also returns the problem to the 'fleshiness' of life, to the human individual and to lived experience. In this context the works of art as well as Toyo Ito's architecture, referred to above, share a common denominator, namely the human individual in the form of the visitor, participant or performer. Ironically, it is the most 'computed' work referred to above, Ikeda's test pattern [100m version], that is closest to architecture. The other two artworks, Forsythe's Nowhere and Everywhere No. 2 and Mandafounis and Mazliah's Eifo Efi, engage the 'visitor' differently. Nowhere and Everywhere sees the visitor as an active participant, able to directly act and influence the space of the installation; Eifo $E f$ stages the visitor as a member of a classical audience. Both, however, remove the visitor from the role that the human individual has in most architecture, namely as an inhabitant.

There will be different vantage points for approaching the conceptual problem discussed herein in practical design work. One approach, pursued in the postgraduate Master of Arts in Architecture program at the Städelschule Architecture Class (SAC), is to isolate and clearly define a materialinformational variable that feeds a design and project space. Having done this, the underlying infrastructure that regulates the workings of this variable can be described and modeled. Without exception, the methods for doing this have included both analogue and digital modeling input. A few examples from this portfolio of 'saturated design problems' are included herein as illustrations to the text. (Fig. 12) 
Jacques Derrida, The Archaeology of the Frivolous, trans. Leavey, John P. Jr., (Lincoln: University of Nebraska Press: Bison Book, 1987). Nelson Goodman, Languages of Art: An Approach to a Theory of Symbols (Indianapolis: The Bobbs-Merrill Company, 1968), 136.

Ibid.,72. Davis quotes Goodman's 1968 version of Languages of Art, p.161.

Ibid., $31-32$.

Ibid., 229- 230.

John von Neumann, "The General and Logical Theory of Automata," in Cerebral Mechanisms in Behavior, ed. Lloyd A. Jeffress (New York: John Wiley \& Sons, 1951), 20,

as quoted by Davis, p.73. A 'switching organ' is the elementary productive unit in a productive system, such as neurons in living organisms and vacuum tubes in computational systems. Davis, "How to Make Analogies in a Digital Age', 136. Arts and Media in Japan. As an installation (the work also comes in other forms), test pattern [100m version] in the Kraftzentrale was the 7th version of the piece. 
See: http://www.ryojiikeda.com/project/testpattern/ - accessed November 2, 2013.

See: http://www.ruhrtriennale.de/en/programm/kuenstler/ryoji-ikeda/ - accessed November 2, 2013.

See: http://www.ruhrtriennale.de/en/programm/produktionen/william-forsythe-nowhere-andeverywhere/ - accessed November 2, 2013.

See: http://www.creativetime.org/programs/archive/2005/Heaven/artists-forsythe.html - accessed November 3, 2013. Brock Labrenz was the dancer.

See: http://mamaza.net/Eifo-Efi/ - accessed November 3, 2013.

For more about this idea, see, for instance, Jaynes, Julian (1982), The Origin of Human

Consciousness in the Breakdown of the Bicameral Mind, (Boston: Houghton Mifflin Company).

In computing and systems design a loosely coupled system is one in which each of its components has, or makes use of, little or no knowledge of the definitions of other separate components. Source: Wikipedia.

Davis, p.77. Davis quotes Goodman, p.192 and p. 149, respectively.

Thomas Daniell, "The Fugitive," in Tarzan in the Media Forest, ed. Thomas Daniell (London: Architecture Words, AA Publications, 2011), 3.

Ibid, p.11.

Ibid, p.12.

Ibid, p.12-13.

Toyo Ito, "Signs of Light," in Tarzan in the Media Forest, ed. Thomas Daniell (London: Architecture Words, AA Publications, 2011), 44.

An example of this is the coexistence of discrete geometric units and material continuity in textile systems.

University of Nebraska Press: Bison Book, 1987.

Goodman, Nelson. Languages of Art: An Approach to a Theory of Symbols. Indianapolis: The Bobbs-Merrill Company, 1968.

Davis, Whitney. "How to Make Analogies in a Digital Age." October 117 (2006): 71.

Neumann, John. "The General and Logical Theory of Automata." In Cerebral Mechanisms in Behavior, ed. Lloyd A. Jeffress, 20. New York: John Wiley \& Sons, 1951.

Daniell, Thomas. „The Fugitive.“ In Tarzan in the Media Forest, ed. Thomas Daniell, 3. London: Architecture Words, AA Publications, 2011.

Ito, Toyo „Signs of Light.“ In Tarzan in the Media Forest, ed. Thomas Daniell, 44. London: Architecture Words, AA Publications, 2011. 
Ako su računari nekada bili veličine objekata, objekti sada postaju računari sposobni da obavljaju I/O komunikacijske protokole ili programirani na molekularnom-nano nivou materijala, ili čak samostalno rade učenju genetskih algoritama.

Ako je javni prostor u kome danas živimo u osnovi izgrađen na početku industrijske revolucije, informacijsko društvo sada donosi nove principe i tehnologije preispitujuć funkcionalnost i strukturu ulica, avenija, trgova i infrastrukture grada.

KLJUČNE REČI: XXXXXXXXXXXXXX, XXXXXXXXXXXXX, XXXXXXXXXXXX, XXXXXXXX, XXXXXXXXXXXXXXXXXXXXXXXX,

\section{KONSTRUISANJE ADAPTIVNIH EKOLOGIJA: U PRAVCU BEHAVIORISTIČKOG MODELA ZA ARHITEKTURU}

\section{Theodore Spyropoulos}

György Kepes (Giorgi Kepes) je jednom objavio, 'U našim novim konceputualnim modelima prirode, stabilni, čvrsti svet materije, koji se u prošlosti smatrao trajnim i predodređenim, se shvata kao široko raspršena polja dinamičkih energija. Materija - opipljiva, vidljiva, stabilna supstanca u staroj slici fizičkog sveta - danas se preformuliše u jednu nevidljivu mrežu nukelarnih događaja sa elektronima koji kružeći putanjom skaču sa jedne na drugu orbitu." Fiksne i konačne tendencije koje su nekada služile da kategorišu prirodne i veštačke svetove su učinjene zastarelim.

Danas ukrštanja informacija, života i materije prikazuju složenosti koje sugerišu mogućnost mnogo dublje sinteze. U okviru tog konteksta, međutim, arhitektura je primorana da radikalno ponovo formuliše svoj odgovor na nove društvene i kulturne izazove i u jednom ubrzanom procesu urbanizacije. Arhitektura danas mora da učestvuje i da se bavi sredinama bogatim informacijama koje oblikuju naše živote konstruišući računarske okvire koji će omogućiti promene, prihvatajući zahtev za adaptativnim modelima života. Naš pristup rešavanja ovih izazova obuhvata istraživanje sistemskih formi interakcije koja se bavi behavioralnim svojstvima koja su poliskalarna, omogućavajući mreže biodiverziteta koje bi delovale između urbanih konteksta, zgrada I materijala. Jedna bliska korelacija materijala i računarskog sadejstva omogućava pojavu generativno vremenski zasnovanog behaviorističkog modela života, gde uzajamno dejstvo lokalnog posredovanja i podsticaja životne sredine izgrađuju kolektivna uređenja. Za razliku od većine veštačkih objekata, arhitekture ovih objekata nisu ugrađene u planovima, već su pre povezane radnje kojima se upravlja kroz nastajuću kolektivnu interakciju. 


\section{OBLICI ZASIĆENOSTI}

Diskretni i neprekidni događaji u arhitektonskom projektovanju

\section{Johan Bettum}

Ovaj esej se bavi mogućnostima i ograničenjima arhitektonskog projektovanja na spoju tehnologije i disciplinarno specifičnih razvoja u arhitekturi. Teoretski model koji se razvija sažima suštine toga šta znači raditi sa odnosnim digitalnim i analogim sistemima modeliranja. On predstavlja oslobađanje od neprekidne krize $\mathrm{u}$ arhitektonskom obrazovanju boreći se sa naletom digitalnog. Osim toga, on se bavi nekritičkom opsednutošću koju arhitektonska akademija ima $\mathrm{u}$ vezi sa tehnologijom bez zapadanja u različite oblike reakcionarnih praksi koje se trenuto pojavljuju u struci kao i u školama.

Diskusija se fokusira na sisteme i režime predstavljanja u arhitektonskom projektovanju i proizvodnji i problematizuje ulogu digitalnih i računarskih projektantskih postupaka u odnosu na analoge sistema predstavljanja, arhitektonske beskrajne izgradnje naše fizičke sredine i svojstvenih ograničenja digitalnih sistema s' obzirom na njihov 'racionalan' karakter.

Ovaj esej pokušava da se razreši uticaj i status digitalnog fokusiranjem na inkluzivni pojam prostora. To je i arhitektonski prostor ali isto tako i prostor produktivnog dizajniranja/projektovanja u kome arhitekte rade. Razvijajući ovaj argument, prodiskutovana su tri umetnička dela i početna pretpostavka za taj argument se zasniva na teoriji umetnosti.

KLJUČNE REČI: ANALOGI SISTEMI PREDSTAVLJANJA; DIGITALNI SISTEMI PREDSTAVLJANJA; DISKRETAN, NEPREKIDAN, INKLUZIVAN; ZASIĆENJE, UČESNIK.

\section{DIGITALNA GROTESKA - KA MIKRO-TEKTONSKOJ ARHITEKTURI}

\section{Michael Hansmeyer, Benjamin Dillenburger}

Računarski dizajn omogućava arhitekturu sa izuzetnim stepenom topografske i topološke složenosti. Ograničenja tradicionalnih CNC tehnologija su sve do nedavno sprečavale arhitekturu da bude fabrikovana. Iako je proizvodnja aditiva omogućila da se ovi složeni oblici materializuju, to je ostvareno samo u veoma maloj razmeri. U pokušaju da se proizvodnja aditiva primeni na konstrukcije arhitekture u punoj razmeri, nailazi se na dilemu: 